\title{
PEMETAAN PERSEBARAN PENYAKIT BUNCHY TOP PADA TANAMAN PISANG DI PROVINSI LAMPUNG
}

\author{
Joko Prasetyo dan Sudiono ${ }^{1}$
}

\begin{abstract}
Distribution mapping of bunchy top of banana in Lampung Province. Studies on the occurrence of banana bunchy top were conducted in Lampung province from March to May 2003. This study were aimed to make distribution map of banana bunchy top in Lampung. The stratified random sampling were used. The sample comprised 6 districts out of 10 districts in Lampung. Three subdistrics were randomly selected in each district and then 3 villages were also selected in each subdistrict. In each village 3 famer"s gardens were selected as observation area. The distribution map shows that banana bunchy top has spread throughout the 6 districts visually observed, but only 4 districts, that bunchy top incidence could be examined. Banana bunchy top incidence in Bandar Lampung, South Lampung, Central Lampung, and North Lampung were 2.31, 2.23, 1.06, and $0.84 \%$ respectively. Bunchy top virus attacked various types, among them are janten (55.23\%), muli (38.88\%), kepok (30.47\%), ambon (21.52\%), raja sere (19.76\%), nangka 4.64\%), and lilin (3.84\%). There were no disease incidence on cultivar tanduk, rejang and susu, thus this fact might be indicated resistance phenomena of these cultivars.
\end{abstract}

Key words: bunchy top virus, banana, and distribution map

\section{PENDAHULUAN}

Provinsi Lampung merupakan daerah penghasil pisang. Namun, tidak semua wilayah tersebut merupakan daerah sentra produksi tanaman pisang. Daerah-daerah yang termasuk sentra produksi tanaman pisang antara lain, Lampung Selatan dengan wilayah Kecamatan Padang Cermin, Kedondong, Penengahan; Kodya Bandar Lampung dengan wilayah Kecamatan Panjang; Lampung Barat; Tanggamus; Lampung Timur dengan wilayah Kecamatan Sekampung, Sukadana; Jabung; Lampung Utara; Way Kanan; Tulang Bawang; Lampung Tengah; dan Kota Metro (Departemen Pertanian, 1991).

Salah satu kendala produksi adalah adanya gangguan organisme seperti hama maupun penyakit. Dua penyakit telah terbukti merugikan di Provinsi Lampung penyakit, yaitu Layu Panama (Fusarium oxysforum f.sp. cubense) dan penyakit layu bakteri (Ralstonia solanacearum) Kedua penyakit meyebakan endemi sehingga produksi berkurang secara signifikan.

Beberapa penyakit lain yang perlu diwaspadai adalah penyakit virus kerdil yang disebabkkan oleh Bunchy Top Virus (BTV), penyakit daun Sigatoka merah (Mycosphaerella musicola), penyakit daun Sigatoka hitam (Mycosphaerella fisiensis). Penyakit kerdil pisang merupakan penyakit baru di Indonesia. Penyakit pertama kali dilaporkan pada Tahun 1978 terdapat di Cimahi dan Padalarang (Kabupaten Bandung) sedangkan di Lampung sampai saat ini belum ada laporan baik intensitas serangan maupun peta penyebarannya. Sejauh ini, informasi tentang keberadaan penyakit BTV di Lampung masih terbatas. Oleh karena itu, perlu dilakukannya penelitian ke daerah-daerah sentra produksi pisang di Lampung untuk mendeteksi serangan penyakit BTV dan memetakan lokasi penyebarannya.

Tujuan penelitian ini adalah (1) Melakukan pemetaan penyebaran penyakit BTV di daerahdaerah sentra produksi pisang di Lampung. (2) Mengetahui intensitas serangan penyakit dan jenis pisang yang terserang penyakit BTV di daerahdaerah sentra produksi pisang di Lampung.

\section{METODE PENELITIAN}

Penelitian dilaksanakan dari bulan MaretMei 2003. Penelitian dilakukan pada pertanaman pisang di daerah-daerah sentra produksi pisang di Provinsi Lampung yaitu Kabupaten Lampung Selatan (Padang cermin, Kedondong, Penengahan), Kabupaten Lampung Tengah (Gunung Sugih, Seputih Raman, dan Bangun Rejo), Kabupaten Lampung Timur (Way Jepara, Purbolinggo, dan Pekalongan), Kabupaten Tanggamus (Talang Padang, Pringsewu, dan Pugung), Kabupaten Lampung Utara (Kota Bumi Utara, Kota Bumi Kota, Kota Bumi Selatan), Kota Bandar Lampung (Panjang, Sukarame, dan Tanjung Karang Barat), dan di Laboratorium HPT Unila.

Alat-alat yang digunakan dalam penelitian ini adalah alat tulis, kuas, botol kecil, alkohol, kalkulator, dan kamera. Bahan yang digunakan dalam penelitian ini adalah literatur tentang penyakit Bunchy Top, laporan tentang daerah-daerah sentra produksi pisang di Lampung dari Dinas Pertanian

${ }_{1}^{1}$ Dosen Jurusan Proteksi Tanaman Fakultas Pertanian Universitas Lampung, Jl. Soemantri Brodjonegoro, 1 Bandar Lampung, 35145. 
dan Ketahanan Pangan Provinsi Lampung dan Badan Pusat Statistik Provinsi Lampung.

Survey yang dilakukan dalam penelitian ini adalah menggunakan cara sampling acak bertingkat. Sampel terdiri dari enam kabupaten dipilih dari sepuluh kabupaten yang merupakan daerah sentra produksi pisang di Provinsi Lampung berdasarkan lahan tanaman pisang yang paling luas. Tiap Kabupaten dipilih tiga kecamatan, kemudian dari setiap kecamatan dipilih tiga desa secara acak. Dalam satu desa dipilih tiga kebun milik petani dengan luas $400 \mathrm{~m}^{2}$ sebagai petak pengamatan.

Survey dilakukan dengan cara pengumpulan data sekunder, wawancara, dan pengamatan lapang.

\section{Pengumpulan Data Sekunder}

Data tentang luas panen tanaman pisang dan produksi tanaman pisang di daerah-daerah sentra produksi pisang di Provinsi Lampung diperoleh dari Dinas Pertanian dan Ketahanan Pangan dan dari Badan Pusat Statistik Provinsi Lampung.

\section{Wawancara}

Melakukan wawancara terhadap petani pemilik kebun pisang untuk mengetahui jenis-jenis pisang yang di tanam dan informasi mengenai penyakit Bunchy Top.

\section{Pengamatan Lapang}

Pengamatan penyakit di lapangan dilakukan terhadap gejala dan penghitungan keterjadian penyakit Bunchy Top dengan rumus

berikut:

$$
\mathrm{K}=\mathrm{n} / \mathrm{N} \times 100 \%
$$

Keterangan:

$\mathrm{K}$ = keterjadian penyakit Bunchy Top (\%)

$\mathrm{n}=$ jumlah batang tanaman pisang yang terserang BTV

$\mathrm{N}$ = jumlah batang tanaman pisang yang diamati

\section{HASIL DAN PEMBAHASAN}

\section{Daerah Penyebaran Penyakit Bunchy Top}

Hasil pengamatan secara kualitatif dengan pengamatan visual menunjukkan bahwa penyakit BunchyTop ditemukan di semua daerah sampel (6 kabupaten/kotamadya di Provinsi Lampung) (Tabel 1). Dalam pengamatan per kecamatan daerah sampel, yang dapat diukur keterjadian penyakitnya secara kuantitatif, yaitu di Kota Bandar Lampung (Kecamatan Raja Basa, Kecamatan Tanjung Karang Barat, dan Kecamatan Teluk Betung Selatan), di Lampung Selatan (Kecamatan Padang Cermin dan Kecamatan Kedondong), di Lampung Utara (Kecamatan Kota Bumi Selatan dan Kecamatan
Kota Bumi Kota), di Lampung Tengah (Kecamatan Gunung Sugih dan Kecamatan Seputih Raman) (Gambar 1).

Penyebaran BTV di Propinsi Lampung tampaknya dari daerah Lampung Selatan, menuju Kota Bandar Lampung, Lampung Tengah, dan kemudian ke daerah Lampung Utara (Gambar 1). Penyebaran ini diduga karena penyakit Bunchy Top pertama kali ditemukan di Jawa dan transportasi dari Jawa ke Lampung masuk melalui daerah Lampung Selatan dan Bandar Lampung. Lampung Selatan dengan areal pertanaman pisang luas memungkinkan tingginya mobilitas pemindahan bibit tanaman pisang dari daerah Jawa ke daerah tersebut maupun sebaliknya.

Menurut Purnomo (1996), penyebaran BTV dalam jarak jauh terjadi melalui serangga vektor atau perpindahan bahan tanaman yang terinfeksi berupa anakan, bonggol dan plantlet kultur jaringan yang secara tidak langsung terbawa masuk ke daerah tersebut.

\section{Pola Penyebaran Penyakit Bunchy Top}

Hasil pengamatan menunjukkan bahwa pola penyebaran penyakit Bunchy Top pada areal pertanaman pisang bersifat mengelompok dan membentuk blok dalam rumpun. Dalam satu rumpun terserang 2 sampai 3 batang tanaman pisang. Di daerah Padang Cermin yang termasuk daerah endemis, dalam satu areal pertanaman hampir semuanya terserang BTV dan penyebarannya membentuk kelompok-kelompok rumpun dalam satu areal.

Pola penyebaran ini berhubungan dengan penularan melalui serangga vektor BTV (Pentalonia nigronervosa) yang tidak aktif terbang. Pentalonia nigronervosa bukan penerbang yang kuat, dapat terbawa oleh angin

kencang, dan puncak aktivitas penerbangannya antara 09.00-11.00 pagi dan 17.00 menjelang petang (Rajan, 1981).

Penularan melalui vektor dapat mencapai jarak sejauh $86 \mathrm{~m}$ dari sumber infeksi (Allen, 1978 dalam Dale, 1986 dalam Purnomo, 1996). Karena itu, jika dalam suatu areal pertanaman telah ada tanaman pisang yang terinfeksi BTV maka tanaman pisang yang berada di areal yang berjarak $\pm 1 \mathrm{~km}$ dapat tertular BTV oleh serangga vektor. Pada areal pertanaman pisang yang tidak ditemukan tanaman pisang yang terinfeksi BTV, maka sulit untuk menemukan tanaman pisang yang terserang BTV pada areal pertanaman pisang di daerah disekitarnya dan sebaliknya. 
Tabel 1. Penyebaran penyakit Bunchy Top di kabupaten/kotamadya di Provinsi Lampung

\begin{tabular}{llcc}
\hline \multirow{2}{*}{ No. } & \multicolumn{2}{c}{ Kabupaten/Kotamadya } & \multicolumn{2}{c}{ Penyakit Bunchy Top } \\
\cline { 3 - 4 } & & ada & tidak ada \\
\hline 1 & Bandar Lampung & $* *$ & - \\
\hline 2 & Lampung Selatan & $* *$ & - \\
\hline 3 & Lampung Tengah & $* *$ & - \\
\hline 4 & Lampung Utara & $*$ & - \\
\hline 5 & Tanggamus & $*$ & - \\
\hline 6 & Lampung Timur & - & - \\
\hline 7 & Lampung Barat + ) & - & - \\
\hline 8 & Way Kanan + ) & - & - \\
\hline 9 & Tulang Bawang +$)$ & - & - \\
\hline 10 & Metro + ) & & - \\
\hline
\end{tabular}

Keterangan: ** Penyakit BunchyTop dapat ditemukan pada daerah tersebut dan keterjadian penyakitnya dapat diukur

* Penyakit Bunchy Top dapat ditemukan pada daerah tersebut tetapi keterjadian penyakitnya tidak dapat diukur

+) Bukan daerah sampel
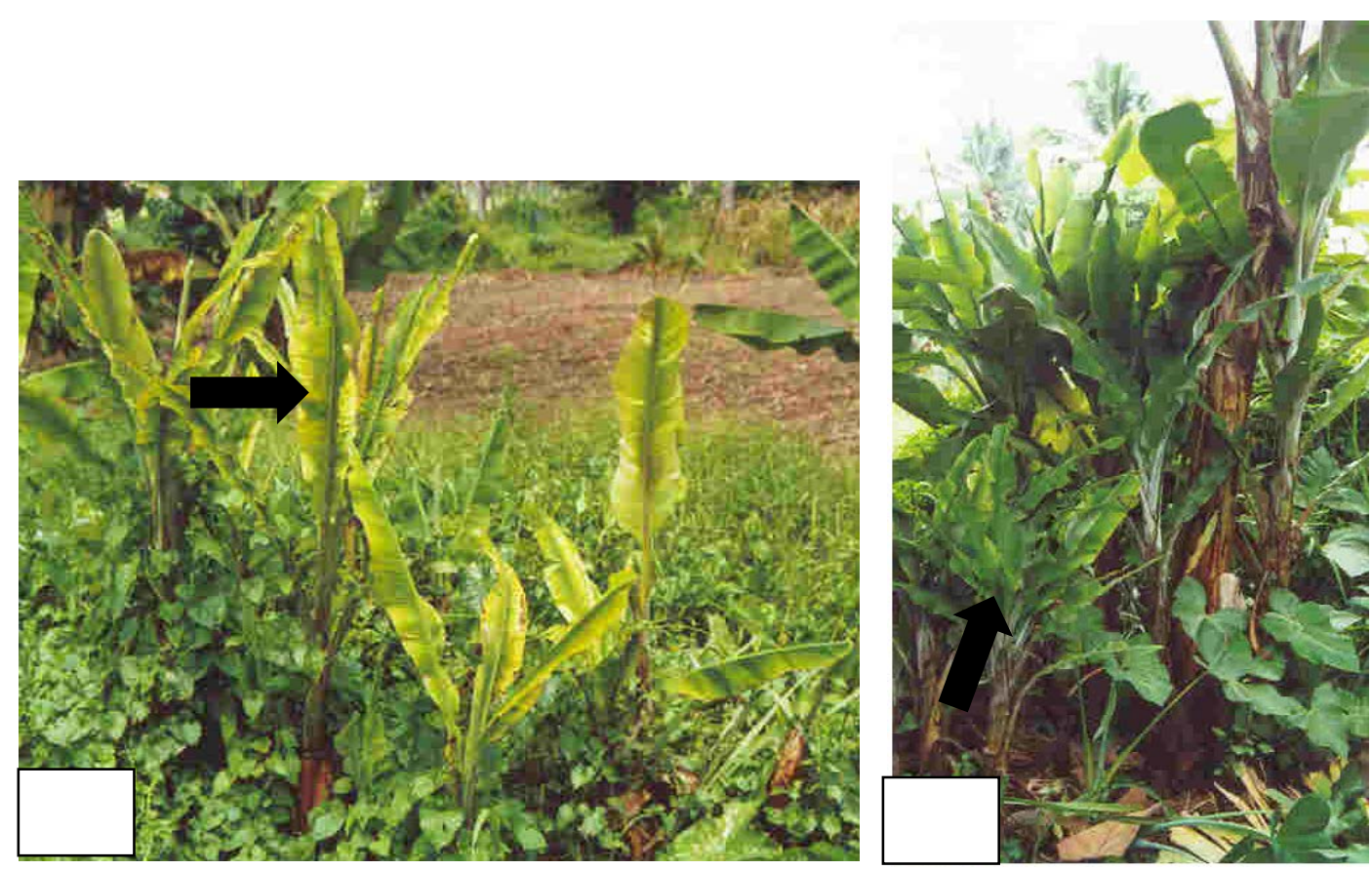

Gambar 2. a. Gejala klorosis pada penyakit Bunchy Top (anak panah), b. Gejala rosset pada penyakit Bunchy Top (anak panah) 


\section{Gejala Penyakit Bunchy Top}

Hasil pengamatan menunjukkan bahwa gejala penyakit Bunchy Top pada tanaman pisang bervariasi dan umumnya yang terserang anakan. Tanaman sakit yang mengalami gejala lanjut mempunyai bentuk kerdil, daun menyempit, lebih tegak, bagian tepi daun menggulung ke atas dan tampak menguning, dan garis-garis klorosis terlihat jelas pada tepi ibu tulang daun (Gambar 2a).

Pada tanaman pisang sakit lainnya, penyakit Bunchy Top menunjukkan gejala rosset yang lebih jelas pada puncak batang palsunya, daunnya lebih tegak, dan klorosis atau garis-garis hijau gelap di sepanjang ibu tulang daun terlihat jelas (Gambar 2b).

Anakan pisang yang terinfeksi BTV menampakkan gejala kerdil tetapi tanaman induk di dekatnya dapat tumbuh normal (tidak terinfeksi) dan dapat berbuah (Gambar 3a). Gejala penyakit Bunchy Top pada tanaman sakit lain yaitu, hanya 1 helai daun saja yang menampakkan gejala klorosis dan terlihat lebih tegak sedangkan daun yang lain terlihat normal, tetapi jika diperhatikan pada puncak batang palsunya menampakkan gejala rosset (Gambar 3b).

\section{Keterjadian Penyakit Bunchy Top}

Hasil perhitungan menunjukkan bahwa keterjadian penyakit Bunchy Top tertinggi ditemukan di Lampung Selatan di Kecamatan Padang Cermin sebesar 4,16\% dan keterjadian penyakit terendah di Lampung Utara di Kecamatan
Kota Bumi Selatan sebesar 0,15\%. Untuk rata-rata per kecamatan keterjadian penyakit tertinggi ditemukan di Kota Bandar Lampung sebesar 2,31\% dan terendah ditemukan di Lampung Utara sebesar 0,84\% (Tabel 2). Hal ini menunjukkan bahwa BTV menyebar dari arah selatan ke arah utara.

Hasil pengamatan menunjukkan bahwa keterjadian penyakit Bunchy Top mempunyai nilai yang berbeda di setiap kecamatan dan kultivar pisang yang terserang BTV pun berbeda. Di daerah Kota Bandar Lampung BTV menyerang kultivar pisang raja sere, janten, muli, ambon, dan kepok. Di daerah Lampung Selatan BTV menyerang kultivar pisang janten, muli, dan ambon. Di daerah Lampung Utara BTV menyerang kultivar pisang janten dan lilin. Di daerah Lampung Tengah BTV menyerang kultivar pisang raja nangka dan kepok.

Serangan BTV tertinggi ditemukan pada areal pertanaman pisang yang banyak naungan phon-pohon besar, dan tercmapur dengan tanaman tanaman lain yang merupakan inang alternatif bagi vektor BTV seperti talas, lengkuas dan gulma. Sedangkan pada areal tanaman pisang yang bersih, terawat dan tidak mempunyai naungan phon-pohon besar, tidak ditemukan tanaman pisang yang terserang BTV, seperti pertanaman pisang di daerah Penengahan, Lampung Selatan
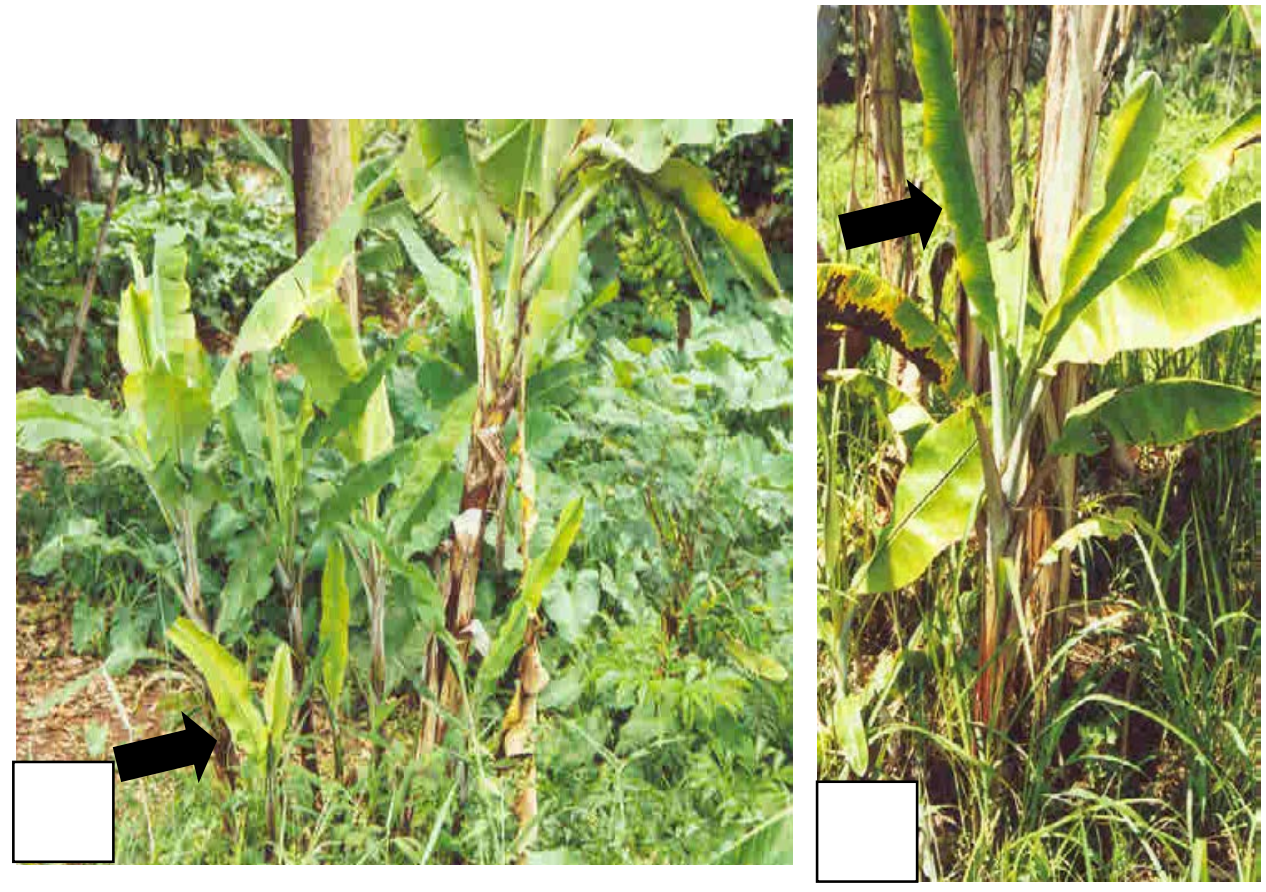

Gambar 3. a. Gejala kerdil penyakit Bunchy Top pada anakan (anak panah), b. Gejala klorosis yang tampak pada 1 helai daun dan rosset pada puncak batang palsunya (anak panah) 


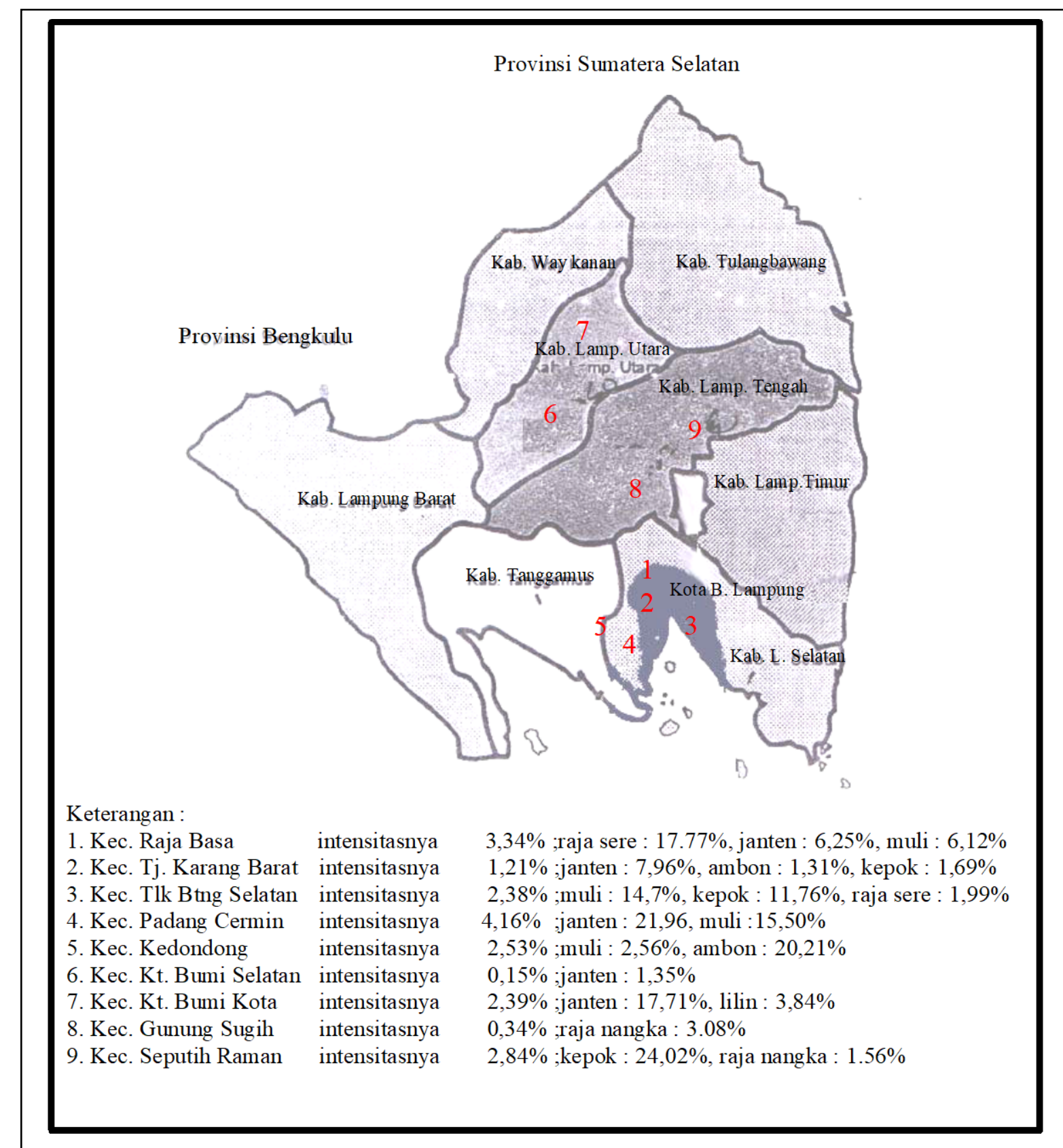

Gambar 1. Peta penyebaran penyakit Bunchy Top dan intensitas (keterjadian) penyakitnya 
Tabel 2. Keterjadian penyakit bunchy top per kecamatan di Provinsi Lampung

\begin{tabular}{|c|c|c|c|}
\hline $\begin{array}{l}\text { Kabupaten/Kota, } \\
\text { Kecamatan }\end{array}$ & $\begin{array}{l}\text { Rata-rata } \\
\text { keterjadian } \\
\text { penyakit Bunchy } \\
\text { Top per kecamatan } \\
\quad(\%)\end{array}$ & $\begin{array}{l}\text { Keterjadianpe } \\
\text { nyakit Bunchy } \\
\text { Top di masing- } \\
\text { masing } \\
\text { kecamatan (\%) }\end{array}$ & $\begin{array}{l}\text { Jenis pisang } \\
\text { yang terserang BTV } \\
\text { dengan keterjadian } \\
\text { penyakitnya }(\%)\end{array}$ \\
\hline Lampung Selatan & 2,23 & & \\
\hline Padang Cermin & & 4,16 & janten $(21,96)$, muli $(15,50)$ \\
\hline Penengahan & & 0 & - \\
\hline Kedondong & & 2,53 & muli $(2,56)$, ambon $(20,21)$ \\
\hline Kota Bandar & 2,31 & & \multirow{5}{*}{$\begin{array}{l}\text { raja sere }(17,7) \text {, janten }(6,25) \text {, muli }(6,12 \\
\text { janten }(7,96), \text { ambon }(1,31) \text {, kepok }(1,69 \\
\text { muli }(14,7), \text { kepok }(4,76), \text { raja sere }(1,99\end{array}$} \\
\hline Lampung & & 3,34 & \\
\hline Raja Basa & & 1,21 & \\
\hline Tanjung Karang Barat & & 2,38 & \\
\hline Teluk Betung Selatan & & & \\
\hline Lampung Tengah & 1,06 & & \\
\hline Bangun Rejo & & 0 & - \\
\hline Gunung Sugih & & 0,34 & raja nangka $(3,08)$ \\
\hline Seputih Raman & & 2,84 & kepok $(24,02)$, raja nangka 1,56$)$ \\
\hline Lampung Utara & 0,84 & & \\
\hline Kota Bumi Selatan & & 0,15 & janten $(1,35)$ \\
\hline Kota Bumi Utara & & & - \\
\hline Kota Bumi Kota & & 2,39 & janten $(17,71)$, lilin $(3,84)$ \\
\hline Tanggamus & 0 & & \\
\hline Talang padang & & 0 & - \\
\hline Pugung & & 0 & - \\
\hline Pringsewu & & 0 & - \\
\hline Lampung Timur & 0 & & \\
\hline Pekalongan & & 0 & - \\
\hline Purbolinggo & & 0 & - \\
\hline Way Jepara & & 0 & - \\
\hline
\end{tabular}




\section{Keterjadian Penyakit BTV pada berbagai Kultivar Pisang}

Kultivar pisang yang terserang BTV mempunyai keterjadian penyakit yang berbedabeda. Keterjadian penyakit tertinggi terdapat pada kutivar pisang janten (55,23\%), pisang muli (38,88\%), dan pisang kepok (30,47\%). Keterjadian penyakit sedang terdapat pada kultivar pisang ambon (21,57\%), dan pisang raja sere $(19,76 \%)$. Sedangkan keterjadian penyakit terendah terdapat pada kultivar pisang raja nangka (4,64\%), dan pisang lilin (3,84\%) (Tabel $3)$.

Tabel 3. Keterjadian penyakit Bunchy Top pada berbagai kultivar pisang di Provinsi Lampung

\begin{tabular}{llcc}
\hline No & Kultivar pisang & $\begin{array}{c}\text { Keterjadian penyakit } \\
\text { Bunchy Top (\%) }\end{array}$ & Standar deviasi \\
\hline 1. & Janten & 55,23 & 1,37 \\
\hline 2. & Muli & 38,88 & 1,409 \\
\hline 3. & Kepok & 30,47 & 1,27 \\
\hline 4. & Ambon & 21,52 & 0,93 \\
\hline 5. & Raja sere & 19,76 & 1,399 \\
\hline 6. & Raja nangka & 4,64 & 0,21 \\
\hline 7. & Lilin & 3,84 & 0,30 \\
\hline 8. & Tanduk & 0 & 0 \\
\hline 9. & Rejang & 0 & 0 \\
\hline 10. & Susu & 0 & 0 \\
\hline
\end{tabular}

Tabel 4. Kultivar dan daerah penyebaran tanaman di Provinsi Lampung

\begin{tabular}{|c|c|c|}
\hline No. & $\begin{array}{c}\text { Kultivar } \\
\text { Pisang }\end{array}$ & Daerah Penyebaran \\
\hline 1. & Muli & $\begin{array}{l}\text { Kota BDL (Rj.Basa,TB.Selatan), L.Selatan (Penengahan, } \\
\text { P.Cermin,Kedondong), Tanggamus (Tlg.Padang,Pugung, } \\
\text { Pringsewu), L.Utara (Kota Bumi Selatan,Kota Bumi Utara,Kota Bumi Kota), } \\
\text { L.Tengah (Bangun Rejo), L.Timur (Pekalongan,Way Jepara) }\end{array}$ \\
\hline 2. & Janten & $\begin{array}{l}\text { Kota BDL (Raja Basa, Tjk. Barat), L.Selatan (P.Cermin, Kedondong), Tanggamus } \\
\text { (Tlg Padang, Pugung), L.Utara (Kota Bumi Selatan, Kota Bumi Utara, Kota Bumi } \\
\text { Kota), L.Tengah (Bangun Rejo), L.Timur (Pekalongan, Purbolinngo,Way Jepara) }\end{array}$ \\
\hline 3. & Kepok & $\begin{array}{l}\text { Kota BDL (Raja Basa, Tjk. Barat, TB.Selatan), L.Selatan (Penengahan, } \\
\text { Kedondong), Tanggamus (Tlg Padang, Pugung, Pringsewu), L.Utara (Kota Bumi } \\
\text { Selatan,Kota Bumi Kota), L.Tengah (Seputih Raman, Bangun Rejo), L.Timur (Way } \\
\text { Jepara) }\end{array}$ \\
\hline 4. & Ambon & $\begin{array}{l}\text { Kota BDL (Tjk.Barat), L.Selatan (Kedondong), L.Utara } \\
\text { (Kota Bumi Selatan), L.Tengah (Seputih Raman, Bangun Rejo), L.Timur (Way } \\
\text { Jepara) }\end{array}$ \\
\hline 5. & Raja nangka & $\begin{array}{l}\text { L.Selatan (Penengahan, Kedondong), L.Tengah (Bangun Rejo, G. Sugih, Seputih } \\
\text { Raman), L.Timur (Way Jepara) }\end{array}$ \\
\hline 6. & Tanduk & $\begin{array}{l}\text { L.Selatan (Penengahan), L.Utara (Kota Bumi Selatan, Kota Bumi Kota), L.Tengah } \\
\text { (Bangun Rejo, G.Sugih) }\end{array}$ \\
\hline 7. & Raja sere & $\begin{array}{l}\text { Kota BDL (Rj.Basa,TB.Selatan), L.Utara (Kota Bumi Selatan), L.Tengah (Seputih } \\
\text { Raman) }\end{array}$ \\
\hline 8. & Lilin & Tanggamus (Pugung), L.Utara (Kota Bumi Utara,Kota Bumi Kota) \\
\hline 9. & Rejang & L.Utara (Kota Bumi Selatan) \\
\hline 10. & Susu & L.Utara (Kota Bumi Kota) \\
\hline
\end{tabular}


Berdasarkan hasil pengamatan pada 6 kabupaten/kotamadya dapat diketahui kultivar pisang yang ditanam di Provinsi Lampung (Tabel 4). Kultivar pisang muli, janten, kepok, dan ambon ternyata banyak ditanam hampir di semua kabupaten/kota di Provinsi Lampung. Kultivar pisang raja nangka dan raja sere juga banyak ditanam di Provinsi Lampung tetapi tidak sebanyak kultivar pisang muli, janten, kepok, dan ambon.

Hal ini berhubungan dengan besarnya minat masyarakat untuk mengkonsumsinya, kemudahan dalam menanam, dan daya tahan kultivar pisang tersebut dalam penyimpanan cukup lama. Sedangkan kultivar pisang lilin, rejang, dan susu masih jarang ditanam di Provinsi Lampung.

\section{SIMPULAN}

Berdasarkan pengamatan dan perhitungan dapat ditarik beberapa simpulan, yaitu : Penyakit Bunchy Top telah menyebar di 6 kabupaten/kotamadya dan hanya 4 kabupaten/kotamadya di Provinsi Lampung yang keterjadian penyakitnya dapat diukur, yaitu di Kota Bandar Lampung (2,31\%), di Kabupaten Lampung Selatan (2,23\%), di Kabupaten Lampung Tengah (1,06\%), dan di Kabupaten Lampung Utara $(0,84 \%)$. BTV menyerang kultivar pisang dengan keterjadian penyakit yang berbeda-beda, yaitu janten (55,23\%), muli (38,88\%), kepok (30,47\%), dan ambon (21,52\%) yang diindikasikan sangat rentan terhadap serangan BTV, raja sere $(19,76 \%)$, nangka (4,64\%), dan lilin (3,84\%) diindikasikan rentan terhadap serangan BTV, sedangkan tanduk (0\%), rejang (0\%), dan susu (0\%) diindikasikan tahan terhadap serangan BTV.

\section{SANWACANA}

Penulis mengucakan terima kasih kepada Irmayani (Alumnus PS HPT FP Unila) atas bantuannya dalam mengumpulkan data dan Universitas Lampung atas bantuan dana penelitian melalui DIKS tahun anggaran 2003.

\section{DAFTAR PUSTAKA}

Anonim. 1999. Banana Bunchy Top Vol. 33 No. 1. Japan International Research Center For Agricultur Sciences. www.yahoo.com. Banana Bunchy Top Virus.

Anonim. 2001. Lampung Dalam Angka 2001. Badan Pusat Statistik Provinsi Lampung. Bandar Lampung.
Brown, J.F. 1980. Plant Protection. Australian Vice-Chancellors'-Committee.

Australia. 438 pp.

Cahyono, B. 1995. Budidaya dan Analisis Usaha Tani Pisang. Kanisius. Yogyakarta.

Dale, J.L., Harding, R.M. 1998. Banana Bunchy Top Disease: Current and Future Strategies for Control. Plant Virus Disease Control. The American Phytopathological Society Press. America. 684 pp.

Departemen Pertanian. 1991. Bercocok Tanam Pisang. Balai Informasi Pertanian Lampung. Bandar Lampung. 24 halaman.

Direktur Jenderal Tanaman Pangan dan Hortikultura. 2000. Laporan Tahunan Satgas Balai Proteksi Tanaman Pangan dan Hortikultura III Lampung Tahun Anggaran 1999/2000. Balai Proteksi Tanaman dan Hortikultura Wilayah III. Satuan Tugas Provinsi Lampung. Bandar Lampung.

Metcalf, R.L. 1962. Destructive and Useful Insects. McGraw-Hill Book Company: New York. 1087 pp.

Purnomo, S. 1996. Pisang. Pusat Penelitian Dan Pengembangan Hortikultura. Balai Penelitian Tanaman Buah.

Rajan, P. 1981. Biology of Pentalonia nigronervosa F. caladii van der Goot, vector of Okatte disease of cardamon. $J$. Plantation Crop 9: 34-41.

Sunarjono, H. 2002. Budidaya Pisang dengan Bibit Kultur Jaringan. Penebar Swadaya. Jakarta. 96 halaman.

Semangun, H. 1996. Penyakit-Penyakit Tanaman Hortikultura di Indonesia. Gadjah Mada University Press. Yokyakarta. 850 halaman.

Stover, R.H. 1972. Banana, Plantain and Abaca Diseases. Commenwealth Mycological Institute Kew Surrey. London. 316 pp.

Waterhouse, D. F. 1987. Chapter 6. Pentalonia nigronervosa Coquerel. pp. 42-49 In Biological Control: Pacific Prospects. D. Waterhouse \& K. R. Norris, Ed. InkataPress: Melbourne. 454 pp.

Zimmerman, E. C. 1948. Insects of Hawaii, vol 5. University of Hawaii Press: Honolulu. 464pp. 